\title{
Manajemen Anestesi pada Pasien dengan Sindroma Eisenmenger yang Menjalani Seksio Sesarea
}

\author{
Dewi Puspitorini Husodo, Scarpia P, Rachma C, Isngadi \\ Departemen Anestesiologi \& Terapi Intensif Fakultas Kedokteran Universitas Brawijaya-RSUP Dr. Saiful; Anwar \\ Malang
}

\begin{abstract}
Abstrak
Pendahuluan sindroma Eisenmenger adalah penyakit jantung bawaan sianotik, termasuk di dalamnya hipertensi pulmonal dengan bidirectional maupun $R-L$ shunt. Penurunan resistensi pembuluh darah sistemik dalam kehamilan akan meningkatan derajat $R-L$ shunt. Mortilitas maternal pada kehamilan dengan sindroma Eisenmenger dilaporkan sekitar 30-70\%. Wanita 35 tahun, gravida 32-33 minggu dengan atrial septal defect (ASD )sekundum $1,5 \mathrm{~cm}$, regurgitasi tricuspid berat, regurgitasi pulmonal sedang, pulmonal hipertensi berat, ejection fraction (EF) $34 \%$, gagal jantung stage C fungsional klas III, sindroma Eisenmenmenger, saturasi preinduksi $90 \%$ dengan non rebreathing mask (NRM) $10 \mathrm{lpm}$. Kasus kedua, wanita gravida 32 minggu dengan ASD sekundum, regurgitasi trikuspid berat, regurgitasi pulmonal sedang, EF 13\%, gagal jantung stage C fungsional klas IV, sindroma Eisenmenger, saturasi preindukasi 66\% dengan non rebreathing mask (NRM) 10 lpm. Keduanya menjalani seksio sesarea dengan anestesi umum. Pada kasus pertama, didapatkan atonia uteri yang menyebabkan perdarahan masif dan penurunan tiba-tiba pada alirah darah balik sistemik yang berujung pada kematian. Pada kasus kedua, pasien tidak dapat beradaptasi dengan aliran darah balik uterus setelah bayi lahir. Hal tersebut menyebabkan penurunan saturasi dan hipotensi yang menurunkan tekanan ventrikel kanan, yang berujung pada kematian. Sebagai simpulan, kehamilan dengan sindroma Eisenmenger memiliki insidensi kematian tinggi. Penanganan intensif multidisiplin diperlukan baik dalam operasi elektif dan gawat darurat. Baik anestesi umum maupun regional memiliki kelebihan dan kekurangan tergantung kondisi pasien saat datang.
\end{abstract}

Kata kunci: penyakit jantung bawaan; seksio sesarea; sindroma eisenmenger

\section{Anesthesia Management in Eisenmenger Syndrome Patient Underwent Caesarean Section}

\begin{abstract}
Eisenmenger syndrome is a cyanotic congenital heart disease that includes pulmonary hypertension with reversed or bidirectional shunt. The decreased of systemic vascular resistance is associated with pregnancy increases the degree of right to left shunting. The maternal mortality rate of pregnancy in the presence of Eisenmenger syndrome is reported 30-70\%. Female 35yo, gravida 32-33 weeks with secundum ASD 1,5cm, severe tricupid regurgitation, moderate pulmonal regurgiation, severe pulmonal hypertension, ejection fraction (EF) 34\%, heart failure stage $\mathrm{C}$ functional class III, Eisenmenger syndrome, preinduction oxygen saturation $90 \%$ on non rebreathing mask $10 \mathrm{lpm}$. Second case, 32 weeks pregnant woman with secundum ASD, severe tricupid regurgitation, moderate pulmonal regurgiation, EF 13\%, heart failure stage D functional class IV, Eisenmenger syndrome, saturation preinduction $66 \%$ on NRM $10 \mathrm{lpm}$. Both of them undergoing section caesaria with general anesthesia. In first case, uterine atony that leads to massive bleeding makes sudden decrease in systemic vascular resistence and may result in sudden death. In second case, the patient can not adapt the uterine back flow after delivery that makes the saturation decrease and sudden hypotention which make insufficient right ventricular pressure leading to mortality. As conclusion, pregnancy with Eisenmenger syndrome has high mortality incidence. Multidicipline high care treatment is needed for this case, both in elective and emergency setting. Both general and regional anesthesia have advantage and disadvantage, depends on the patient condition.
\end{abstract}

Key words: congenital heart disease; caesarean section; eisenmenger syndrome 


\section{Pendahuluan}

Victor Eisenmenger awalnya menjelaskan "Eisenmenger complex" pada tahun 1897 dalam suatu artikel mengenai defek kongenital pada sistem ventrikel. Pada tahun 1958, sebuah jurnal mendefinisikan sindroma tersebut sebagai hipertensi pulmonal akibat resistensi vaskuler paru pulmonary vascular resistance (PVR) yang tinggi dengan shunt yang berbalik arah (kanan ke kiri) atau bidirectional (dua arah) pada level aortopulmonal, ventrikel, atau atrial. ${ }^{1}$ Pasien dengan sindroma Eisenmenger memiliki tingkat survival setinggi $80 \%$ pada 10 tahun setelah diagnosis, dan $42 \%$ pada 25 tahun. Mortalitas yang signifikan terjadi pada pembedahan nonkardiak dan kehamilan. Pasien dengan penyakit vaskuler pulmonal menghadapi risiko perioperatif potensial yang signifikan dan termasuk dalam kelompok pasien dewasa yang mungkin dikonsulkan untuk evaluasi anestesi sebelum pembedahan nonkardiak. ${ }^{1,2}$ Mortalitas maternal pada pasien dengan sindroma Eisenmenger sangat tinggi, mulai dari 23\% sampai 50\%. Wanita dengan hipertensi pulmonal atau sindroma Eisenmenger seharusnya tidak hamil dan terminasi terapeutik perlu ditawarkan bila pasien datang pada awal kehamilan. ${ }^{1,2}$

\section{Kasus}

Kasus 1 Seorang wanita, 35 tahun, rujukan dengan diagnosis gravida 32-33 minggu (+) ASD secundum (+), hipertensi pulmonal (+) EF 34\% dengan keluhan utama sesak nafas sejak 3 tahun yang lalu, memberat 3 hari sebelum MRS. Sesak saat beraktivitas $(+)$, orthopnea $(+)$, paroxysmal nocturnal dyspnoe $(+)$. Keluhan disertai dengan tungkai bengkak sejak sejak 2,5 tahun yang lalu setelah melahirkan anak kedua (2011). Pasien didiagnosis dengan penyakit jantung sejak saat itu oleh spesialis jantung di RSUD Kepanjen dan tidak rutin kontrol. Riwayat dua persalinan sebelumnya secara spontan, tanpa ada keluhan. Pada pemeriksaan fisik, pasien tampak sakit sedang dengan kesadaran compos mentis, laju napas 26-28 x/mnt, saturasi 90-92\% (dengan non-rebreathing mask $10 \mathrm{lpm}$ ). Tekanan darah $130 / 80 \mathrm{mmHg}$ dengan dobutamin $5 \mathrm{mcg} / \mathrm{kg} / \mathrm{min}$, laju nadi $95-100 \mathrm{x} /$ menit reguler kuat angkat, suara jantung 1 dan 2 tunggal reguler, murmur $(+)$ 3/6 PM di ICS 4 parasternal line kiri. Produksi urin $50 \mathrm{cc} / \mathrm{jam}$, kuning jernih. Didapatkan edema tungkai dan clubbing finger. Tinggi fundus uteri antara umbilikus dan proccessus xhypoideus. Hasil pemeriksaan darah lengkap, faal hemostatis, serum eletrolit, gula darah, albumin, fungsi ginjal, dan fungsi hati dalam batas normal. Hasil analisa gas darah menunjukan acute respiratory distress syndrome sedang dan alkalosis respiratorik, analisa gas darah: $\mathrm{PH} 7,48 / \mathrm{pCO}_{2} 36 / \mathrm{pO}_{2} 89,7 /$ $\mathrm{HCO}_{3}+27,4 /$ base excess 3,3/ saturasi 97,4 (p/f ratio 147,0 Hasil EKG menunjukan $\mathrm{RVH}$, RBBB komplit, T inversi II, III, AVF. Hasil rontgent menunjukan kardiomegali dengan CTR $60 \%$, cardiac waist, apex round. Hasil echocardiography menunjukan hasil dimensi ruang jantung LA, LV normal, RV dilatasi, fungsi sistolik LV: EF 34\%, fungsi diastolik LV: EA 0,6, fungsi sistolik RV: TAPSE $2,2 \mathrm{~cm}$. Fungsi katub jantung MV, AV normal, TR severe, PR mild, MPA dilatasi, tampak MPA-aorta, shunting tidak jelas, septal diskinetik, MPAP $56 \mathrm{mmHg}$. Defek IAS ukuran $1,7 \mathrm{~cm}$, bidirectional, dominan $\mathrm{L}$ to $\mathrm{R}$ shunt. Hasil NST menunjukkan baseline rate $140 \mathrm{x} / \mathrm{m}$, variabilitas $5-10 \mathrm{x} / \mathrm{m}$, acc (+), decc (-), normal CTG. Hasil USG menunjukan implantasi placenta di corpus lateral sinistra meluas menutupi seluruh OUI, janin intrauterin $\mathrm{T} / \mathrm{H}$, letak bujur kepala dibawah, 28w3d, EFW $1267 \mathrm{~g}$, AFI 11,1. Pasien ini didiagnosa G3P0202 Ab000 gr 32-34 minggu tunggal hidup $\mathrm{T} / \mathrm{H}$ dengan ASD sekundum $1,5 \mathrm{~cm}$, regurgitasi tricuspid berat, regurgitasi pulmonal sedang, pulmonal hipertensi berat, EF 34\%, Heart Failure Stage C Functional class III, sindroma Eisenmenger, intrauterine growth restriction, dan perdarahan antepartum et causa placenta previa totalis. Pasien direncanakan seksio sesarea dengan anestesi umum.

\section{Intraoperatif}

Pukul 07.45-08.15: Pemasangan kateter epidural dan $\mathrm{CVC} \rightarrow$ CVC $14-16 \mathrm{mmHg}$

Pukul 08.20-08.30: Induksi anestesi dengan midazolam 4mg, fentanyl 100ug x 4, vecuronium $5 \mathrm{mg}$, NE $0,1 \mathrm{mcg} / \mathrm{kg} / \mathrm{min}$. Dilanjutkan dengan 
intubasi dengan ETT no 6,0. Pasca intubasi, pernafasan dikontrol dengan ventilator.

\section{Pasca Intubasi}

Pada pemeriksaan breathing (B1) didapatkan airway paten, nafas dikontrol ventilator mode volume control $14-18 \mathrm{x} / \mathrm{m} \mathrm{O}_{2} \quad 100 \% \mathrm{SpO}_{2}$ 9497\%, pemeriksaan blood (B2) didapatkan akral hangat, kering, merah, nadi reguler, kuat angkat, frekuensi $70-100 \mathrm{x} / \mathrm{m}$, tekanan darah 100-150/70-80, murmur +, CVP 9-18mmHg dengan dobutamin $5 \mathrm{ug} / \mathrm{kg} / \mathrm{min}$, NE 0,1-0,3ug/ $\mathrm{kg} / \mathrm{min}$. pemeriksaan brain (B3) menunjukkan tidak dapat dievaluasi, pada pemeriksaan bladder (B4) Kateter urine positif dengan volume $150 \mathrm{ml}$ lalu dibuang, pada pemeriksaan bowel (B5) didapatkan tinggi fundus uteri (TFU) pertengahan umbilikus-processus xyphoideus, sedangkan pada pemeriksaan bone (B6) didapatkan edema positif, dan clubbing finger positif.

Pukul 08.00 hingga 08.30 didapatkan hasil pada pemeriksaan breathing (B1) Airway paten, controlled respiration $16-20 \mathrm{x} / \mathrm{m} \mathrm{O}_{2} 100 \% \mathrm{SpO} 2$ 89-100\%, blood (B2) Akral dingin, kering, pucat, clubbing finger + , nadi reguler, kuat angkat,frekuensi $70-100 x / m$, TD 80-150/4580, murmur +, CVC $14-18 \mathrm{mmHg}$ dengan Dobutamin $10 \mathrm{ug} / \mathrm{kg} / \mathrm{min}$, NE $0,3-0,5 \mathrm{ug} / \mathrm{kg} / \mathrm{min}$, pada pemeriksaan brain (B3) hasil tidak dapat dievaluasi,pemriksaan bladder (B4) dengan terpasang kateter urine positif dengan volume $0 \mathrm{ml}$. Pemeriksaan bowel (B5) didapatkan bayi lahir pada pukul 08.35 dengan AS 1-5-5, dan pada pemerikasaan bone (B6) didapatkan edema positif. Pukul 08.40 bayi lahir dan dimulai injeksi Methergin $0,2 \mathrm{mg}$ pelan, dilakukan pengambilan PRC 3 labu, output perdarahan sebesar $1000 \mathrm{ml}$ dengan urine $0 \mathrm{ml}$, sedankan input cairan NS sebanyak $500 \mathrm{ml}$ dan Haes $1000 \mathrm{ml}$ serta packed red cell (PRC) $420 \mathrm{ml}$.

Pukul 09.00 hingga 09.15 WIB didapatkan pemriksaan breathing (B1) dengan hasil airway paten, controlled respiration 16$20 \mathrm{x} / \mathrm{m} \mathrm{O}_{2} \quad 100 \% \mathrm{SpO}_{2} 39-100 \%$, pemeriksaan blood (B2) dengan hasil akral dingin, basah, sianosis, Clubbing finger positif, Nadi Reguler, lemah, frekuensi $30-80 \mathrm{x} / \mathrm{m}$, TD tidak terukur, murmur positif, CVC $14-18 \mathrm{mmHg}$ diinjeksikan SA $0,5 \mathrm{mg}$ (09.08), dobutamin $10 \mathrm{ug} / \mathrm{kg} / \mathrm{min}$, norepineprin (NE) $0,5 \mathrm{ug} / \mathrm{kg} / \mathrm{min}$, pemeriksaan brain (B3) menunjukkan tidak dapat dievaluasi, hasil pemeriksaan bladder (B4) volume $0 \mathrm{ml}$, pemeriksaan bowel (B5) menunjukkan bayi lahir 08.35 AS 1-5-5, perdarahan masif ec atonia uteri dan pada pemeriksaan bone (B6) didapatkan edema positif. Sedangkan output perdarahan sebanyak $1600 \mathrm{ml}$, urine $0 \mathrm{ml}$, input cairan NS $750 \mathrm{ml}$, Haes $1750 \mathrm{ml}$, PRC $500 \mathrm{ml}$. Berdasarkan kondisi ini diputuskan dilakukan tindakan histerektomi.

Pukul 09.15 WIB terjadi henti jantung dengan PEA asystole, dilakukan resusitasi jantung paru (RJP) unsyncronized $100 \mathrm{x} / \mathrm{menit}, 20 \mathrm{x} / \mathrm{m}$ dan injeksi epinefrin $1 \mathrm{mg} / 2-3$ menit sebanyak 7 kali hingga pada pukul 09.30 WIB didapatkan kondisi pasien no response, midriasis maksimal dengan output cairan perdarahan sebanyak $2600 \mathrm{ml}$, urine $0 \mathrm{ml}$, input cairan NS sebanyak $1000 \mathrm{ml}$, Haes sebanyak 2000ml, dan PRC $630 \mathrm{ml}$ dan pasien dinyatakan meninggal

\section{Kasus 2}

Pasien Ny. H, 29 tahun, datang ke unit gawat darurat RSSA rujukan dari Tumpang dengan kehamilan dan dicurigai gagal jantung. Pasien mengeluh sesak sejak 2 bulan sebelum masuk rumah sakit terutama saat beraktivitas, yang berkurang dengan istirahat. Sejak 2 minggu sebelum masuk rumah sakit pasien mengeluh sesak memberat, sesak bertambah dengan posisi tidur, kedua kaki bengkak. Pasien sedang hamil 32-34 minggu dengan ante natal care (ANC) rutin ke bidan 1x/bulan. Anak pertama lahir normal spontan di bidan, 5 tahun yang lalu. Pada pemeriksaan fisik, pasien tampak sakit berat dengan GCS 2: 2: 4, laju pernafasan 40$50 \mathrm{x} /$ menit, ronkhi penuh di semua lapang paru, saturasi oksigen $66-70 \%$ dengan non rebreathing mask $10 \mathrm{lpm}$. Akral sianosis, dingin, basah, nadi 120-140x/menit, tekanan darah 160/100 $\mathrm{mmHg}$, murmur sistolik di apex dan ICS V PSL S gr $4 / 6$. Produksi urin $20 \mathrm{cc} / \mathrm{jam}$. Hasil pemeriksaan faal hemostatis, serum elektrolit, gula darah, albumin, fungsi ginjal, dan fungsi hati dalam batas normal. Hasil pemeriksaan darah lengkap menunjukan 
trombositopenia dengan trombosit 130.000. Hasil analisa gas darah menunjukan acute respiratory distress syndrome (ARDS) berat dan alkalosis respiratorik, dengan hasil AGD $\mathrm{PH} 7,33 / \mathrm{pCO}_{2}$ $25,2 / \mathrm{pO}_{2} 52,5 / \mathrm{HCO}_{3}+13,4 /$ base excess $-12,8 /$ $\mathrm{O}_{2}$ sat 84,8 (pf ratio 86,0). Hasil rontgent dada menunjukan edema paru dan kardiomegali (gambar III).

Hasil echocardiography menunjukan hasil dimensi ruang jantung LA dan LV normal, RV dan RA dilatasi, fungsi sistolik LV: EF 13\%. Fungsi katub jantung TR severe, PR moderate, PH mild (mpap 40). Didapatkan ASD sekundum besar dengan aliran $\mathrm{R}$ to $\mathrm{L}$ shunt, sindroma Eisenmenger (gambar IV). Pasien ini didiagnosa G2P1001Ab000 gr 32-34 minggu $\mathrm{T} / \mathrm{H}$ dengan ASD sekundum $1,5 \mathrm{~cm}$, regurgitasi tricuspid berat, regurgitasi pulmonal sedang, pulmonal hipertensi ringan, EF 12\%, Heart Failure Stage D Functional class IV, sindroma Eisenmenger, trombositopenia dan fetal distress. Pasien direncanakan direncanakan seksio sesarea cito di IGD. Keluarga diedukasi mengenai kondisi pasien dan prognosis dubia ad malam; pasien dapat meninggal sewaktu-waktu sebelum dan saat anestesi serta operasi.

\section{Durante Operasi}

Pukul 05.50 dilakukan pemeriksaan breathing (B1) dengan hasil pemeriksaan RR 40-50x/menit, $\mathrm{Rh}+/+$ Wh -/-, dengan NRBM $10 \mathrm{lpm}, \mathrm{SaO}_{2} 30$ $40 \%$, pemeriksaan blood (B2) didapatkan hasil akral sianosis, dingin, N 115-120x/menit, $\mathrm{T}$ 118/70, dobutamin $3 \mathrm{ug} / \mathrm{kg} /$ ', pemeriksaan brain (B3) kondisi tampak sangat sesak, pemeriksaan bladder (B4) didapatkan hasil produksi urin 20 cc/jam, pemeriksaan bowel (B5) didapatkan hasil gravida 32-34 minggu, dan pada pemeriksaan bone (B6) didapatkan edema positif dan pasien sianotik. Pasien diinduksi dengan menggunakan Midazolam 2,5 mg, Fentanyl 50 ug, Ketamine $25 \mathrm{mg}$ dan Vecuronium $4 \mathrm{mg}$. Selama operasi, obat-obat yang diberikan terdiri dari Inline dobutamin 3-10 ug/kg/', oksitosin $10 \mathrm{iu}$, dengan disertai pemberian obat emergensi epinefrin total 15 ampul dan sulfas atropin (SA) sebanyak 10 ampul. Perhitungan balans cairan berupa input cairan koloid (HES) sebanyak $500 \mathrm{cc}$ dengan output cairan yang terdiri dari perdarahan sebanyak $400 \mathrm{cc}$ dan produksi urine $50 \mathrm{cc}$ dalam 30 menit. Pasien dinduksi jam 05.50, kemudian insisi dilakukan jam 05.53. Bayi lahir jam 06.00. Setelah bayi lahir, diberikan oxytocin dan pasien henti jantung jam 06.05. Saat henti jantung dilakukan resusitasi jantung-paru, akan tetapi pasien tidak berespon. Pasien dinyatakan meninggal jam 06.55.

\section{Pembahasan}

Pada kehamilan terjadi perubahan fisiologi yang cukup signifikan di berbagai sistem organ. Perubahan tersebut secara fisiologis akan membebani jantung. Pasien dengan kelainan jantung yang mengalami kehamilan akan menerima beban yang semakin berat dan berisiko tinggi terjadinya gagal jantung. Pada kasus pertama, pasien kelainan jantung kongenital berupa ASD sekundum sejak lahir dan kompensasi dari tubuhnya sedemikian rupa sampai dengan terjadi hipertensi pulmonal berat yang semakin meningkatkan risiko terjadinya gagal jantung sampai dengan Eisenmenger sindroma yang berisiko kematian. Pada pasien ini sebelum dilakukan tindakan terminasi telah terjadi bidirekcional shunt dengan aliran dominan dari kiri ke kanan. Pasien juga memiliki kondisi hipertensi pulmonal berat dengan nilai PASP yang cukup tinggi sampai dengan 132 $\mathrm{mmHg}$ dimana jika tekanan darah sistol dari ventrikel kiri turun dibawah nilai tersebut maka risiko untuk terjadinya aliran darah dari kanan ke kiri semakin besar. Teknik anestesi pada pasien dengan sindroma Eisenmenger memiliki perbedaan pendapat dari beberapa laporan kasus, ada yang memilih dengan anestesi umum dan ada yang memilih dengan regional anestesi dengan epidural. Alasan yang dikemukakan baik itu regional ataupun anestesi umum adalah masingmasing teknik lebih kecil menurunkan SVR. Pada regional anestesi, tidak terjadi manipulasi dari tekanan intratorakal dengan pemberian ventilasi tekanan positif melainkan dengan tarikan nafas pasif sesuai fisiologi pasien. Ventilasi tekanan positif dapat memperberat hipertensi pulmonal yang terjadi. ${ }^{8}$ 
Selama operasi pasien mengalami atonia uteri diduga, karena hipoksia lama dan gangguan koagulasi. Terjadi perdarahan masif sampai dengan di akhir operasi melebihi estimated blood volume pasien. Pada awal resusitasi cairan diberikan koloid, produk darah masuk 20 menit setelah bayi lahir ketika perdarahan mencapai $800 \mathrm{ml}$. Ketika perdarahan mencapai $1600 \mathrm{ml}$ dan tetap belum berhenti, diputuskan untuk dilakukan histerektomi. Pasien dinyatakan meninggal setelah terjadi perdarahan sampai dengan $2600 \mathrm{ml}$ saat proses histerektomi hampir selesai. Perdarahan masif menurunkan SVR dan memperberat right to left shunt ( $\mathrm{R}$ to $\mathrm{L}$ shunt), pemberian produk darah yang terlambat memperburuk kondisi pasien. Teknik anestesi umum dengan pemberian ventilasi tekanan positif juga diduga dapat memperberat hipertensi pulmonal, sehingga memperberat $R$ to L shunt. ${ }^{8}$ Uterotonika yang dipilih pada pasien adalah metergin, karenaefeknyayangdapatmenyebabkan takikardi dan hipertensi, tidak diberikan oksitosin karena dapat menyebabkan hipotensi. Kondisi penurunan SVR akan memperberat aliran $R$ to $L$ shunt. Pada kasus pasien kedua, penurunan SVR menyebabkan peningkatan right to left shunt, yang memperburuk saturasi arterial dan hipoksemia, serta kemungkinan besar menginduksi terjadinya disfungsi miokard pada ventrikel kanan yang telah terbebani. Pada pasien ini saturasi awal induksi sangat rendah (saturasi dengan non rebreathing mask $10 \mathrm{lpm}$ 64-67\%), terjadi hipoksemia berkepanjangan dan kondisi asidosis metabolik berat akibat proses metabolik anaerob, akibatnya kompensasi sel menjadi tidak optimal. Kondisi anemia akan menurunkan suplai oksigen miokard dan hipoksemia dengan meningkatkan pulmonary vascular resistance serta stress ventrikel kanan selanjutnya dapat memperberat efek merugikan dari penurunan SVR dan meningkatkan right to left shunt. Dapat dikatakan bahwa anemia, penurunan SVR, peningkatan PVR, hipoksemia, dan stresor pada ventrikel kanan merupakan dasar penyebab disfungsi dan gagal ventrikel kanan, dan outcome yang jelek pada pasien dengan sindroma Eisenmenger, serta merupakan alasan di balik mortalitas yang tinggi pada pasien hamil. Periode persalinan merupakan periode yang meningkatkan stresor bagi pasien hamil dengan sindroma Eisenmenger. Kontraksi uterus dan lahirnya bayi menyebabkan peningkatan SVR yang signifikan dan mobilisasi sejumlah besar volume darah ke sirkulasi, yang dapat sangat meningkatkan preload jantung, stresor ventrikel kanan, afterload ventrikel kiri, dan gagal ventrikel (kanan dan kiri) akut. ${ }^{6}$

\section{Sindroma Eisenmenger dalam Kehamilan}

Sindroma Eisenmenger didefinisikan sebagai perkembangan hipertensi pulmonal sebagai respon terhadap left-to-right, shunt jantung dengan konsekuensi aliran shunt bidirectional atau berkebalikan (right-to-left). Awalnya, leftto-right shunting intrakardiak dihubungkan dengan peningkatan aliran (dan terkadang transmisi tekanan) melalui vaskuler pulmonal. Hal ini menyebabkan remodeling vaskuler pulmonal dan mengakibatkan timbulnya penyakit vaskuler pulmonal. Hipertensi arterial pulmonal dan peningkatan tekanan jantung kanan menyebabkan berbaliknya shunt menjadi rightto-left atau bidirectional, yang disebut sindroma Eisenmenger. ${ }^{3-5}$ Defek jantung kongenital yang dapat menimbulkan sindroma Eisenmenger meliputi: atrial septal defect, ventricular septal defect, persistent arterial duct, serta defek yang lebih kompleks seperti atrioventricular septal defect, truncus arteriosus aorta pulmonary window, complex pulmonary atresia, dan univentricular heart. Akibat dari right-to-left shunt, pasien mengalami hipoksemia kronis, dan menjadi sianotik. Sindroma Eisenmenger dihubungkan dengan komplikasi pada banyak sistem dan dianggap sebagai kelainan multisistim. ${ }^{3,4}$

Komplikasi kardiak meliputi: aritmia supraventrikuler, aritmia ventrikel, gagal jantung kongestif, penyakit katup progresif, kematian mendadak.

Komplikasi nonkardiak meliputi: perdarahan (perdarahan pulmonal, gastrointestinal, serebral), komplikasi iskemik (kejadian tromboembolik, emboli paradoksikal, emboli udara), disfungsi ginjal, gejala yang berhubungan dengan hiperviskositas defisiensi besi (akibat flebotomi yang tidak sesuai untuk eritrositosis sekunder), 
dilatasi arteri pulmonalis, infeksi (endokarditis, abses serebral, pneumonia), gout, hypertrophic pulmonary osteoarthropathy.

Perubahan hemodinamik pada kehamilan biasanya tidak dapat ditoleransi pada wanita dengan sindroma Eisenmenger. Sebagian besar wanita dengan sindroma Eisenmenger berada dalam kondisi seimbang dan prinsip perawatan utama adalah tidak mengganggu keseimbangan tersebut. Pada wanita sindroma Eisenmenger dengan kondisi cardiac output rendah, ventrikel kanan yang telah terbebani tidak dapat memenuhi kebutuhan dari peningkatan volume darah dan cardiac output akibat kehamilan. Selain itu, resistensi vaskuler paru yang menetap dengan akibat ketidakmampuan meningkatkan aliran darah pulmonal, tidak dapat mengakomodasi peningkatan cardiac output. Selain itu, fluktuasi volume darah saat pre dan postpartum tidak dapat ditoleransi oleh sistim kardiovaskuler yang telah terbebani, penurunan resistensi vaskuler perifer yang terjadi selama kehamilan dapat meningkatkan right-to-left shunting, memperburuk hipoksemia maternal dan sianosis. Selama kehamilan, darah menjadi semakin hiperkoagulan dan pada pasien sianotik terjadi peningkatan risiko deep vein thrombosis, infark pulmonal, dan/atau embolus paradoksal dan stroke. $^{6}$

Kehamilan merupakan penyebab mortalitas yang signifikan pada wanita dengan sindroma Eisenmenger. Tinjauan sistematis terhadap studi-studi yang dipublikasi tahun 1978-1996 mengenai tingkat mortalitas pada pasien dengan sindroma Eisenmenger menunjukkan tingkat mortalitas sebesar 56\%. Tinjauan yang lebih baru menunjukkan bahwa mortalitas tetap tinggi. Sebagian besar komplikasi terjadi saat mendekati aterm atau masa awal (minggu pertama) postpartum, sehingga disarankan observasi postpartum di rumah sakit. Mortalitas umumnya terjadi akibat gagal jantung, kematian mendadak disebabkan oleh aritmia atau kejadian tromboembolik. Selama kehamilan, penting untuk mengobservasi gejala-gejala kardiak meliputi peningkatan kelelahan, edema perifer semakin berat, palpitasi, nyeri dada yang dapat merefleksikan iskemia ventrikel kanan, dan/atau overload volume dan presinkop/sinkop dengan aktivitas yang merefleksikan penurunan cardiac output. Namun komplikasi lain seperti yang telah dijelaskan juga dapat terjadi, khususnya tromboemboli. ${ }^{7}$

Keguguran sering terjadi pada wanita yang sianotik. Restriksi pertumbuhan intrauterus ditemukan pada $30 \%$ kehamilan sebagai akibat dari hipoksemia maternal. Kelahiran prematur ditemukan pada $50-60 \%$ kejadian dan tingkat mortalitas perinatal yang tinggi (28\%) disebabkan terutama oleh prematuritas. Dalam satu studi pada wanita dengan sindroma Eisenmenger, 47\% melahirkan aterm, $33 \%$ antara 32 dan 36 minggu, dan 20\% sebelum 31 minggu kehamilan. Perubahan kardiovaskuler selama kehamilan ditujukan untuk meningkatkan cardiac output untuk memastikan suplai oksigen dan nutrisi ke fetus yang sedang tumbuh. Perubahan besar yang terjadi meliputi ekspansi volume darah, hemodilusi, dan penambahan plasenta yang memiliki resistensi vaskuler yang rendah ke dalam sirkulasi sistemik. Volume darah mulai meningkat pada kehamilan 6 minggu, dan pada akhir kehamilan, volume mencapai sekitar 50\% lebih banyak daripada kondisi sebelum hamil. Massa sel darah merah meningkat sebanyak $40 \%$ di atas nilai sebelum hamil; peningkatan volume plasma lebih besar daripada peningkatan massa sel darah merah, dan akibatnya terjadi hemodilusi yang menjelaskan kondisi anemia fisiologis pada kehamilan. Perubahan-perubahan tersebut, baik hemodilusi, anemia relatif, penurunan viskositas, maupun penambahan sirkulasi plasental ke dalam sirkulasi sistemik dapat menyebabkan penurunan resistensi vaskuler sistemik systemic vascular resistance (SVR) yang signifikan. Perubahan hemodinamik ini pada pasien hamil dengan sindroma Eisenmenger menyebabkan dekompensasi jantung dan berpotensi membahayakan.

Pada pasien dengan sindroma Eisenmenger, penurunan SVR menyebabkan peningkatan right to left shunt, yang memperburuk saturasi arterial dan hipoksemia, serta kemungkinan besar menginduksi terjadinya disfungsi miokard pada ventrikel kanan yang telah terbebani. Anemia 
menyebabkan penurunan suplai $\mathrm{O}_{2}$ miokard, hipoksemia meningkatkan PVR dan stres ventrikel kanan selanjutnya akan memperberat efek merugikan dari penurunan SVR dan meningkatkan right to left shunt. Dapat dikatakan bahwa anemia, penurunan SVR, peningkatan PVR, hipoksemia, dan stres ventrikel kanan merupakan dasar penyebab disfungsi dan gagal ventrikel kanan, dan outcome yang jelek pada pasien dengan sindroma Eisenmenger, serta merupakan alasan di balik mortalitas yang tinggi pada pasien hamil. ${ }^{6}$

Fase dimulainya persalinan merupakan periode yang meningkatkan stresor bagi pasien hamil dengan sindroma Eisenmenger. Kontraksi uterus dan turunnya bayi menyebabkan peningkatan SVR yang signifikan dan mobilisasi sejumlah besar volume darah ke sirkulasi, yang dapat meningkatkan preload jantung, tekanan ventrikel kanan, afterload ventrikel kiri, dan gagal ventrikel (kanan dan kiri) akut. Perencanaan persalinan sesarea dilakukan ketika fetus sudah berkembang adekuat untuk menghindari persalinan normal dan memanipulasi SVR dengan melakukan anestesia spinal, sehingga tercapai hasil yang sukses. Kemungkinan, selama manajemen pasien dengan sindroma Eisenmenger yang menjalani pembedahan insidental, pencegahan penurunan akut SVR dan hemodilusi dapat mencegah kolaps kardiovaskuler akut dan memperbaiki outcome perioperatif. Meskipun demikian, penting untuk mengetahui bahwa peningkatan SVR yang tidak terkendali dapat menyebabkan gagal ventrikel kanan dan kiri, sehingga harus dihindari. Penggantian kehilangan darah dengan cairan dapat mempresipitasi terjadinya gagal ventrikel kanan akut. Sindroma Eisenmenger merupakan kondisi penyakit dimana konservasi darah tidak memiliki tempat dan kehilangan darah harus diganti dengan sel darah merah. ${ }^{7}$

\section{Konseling Prekonsepsi/Metode Kontrasepsi}

Berdasarkan risiko mortalitas yang tinggi saat kehamilan dan peripartum, wanita dengan sindroma Eisenmenger dianjurkan untuk tidak hamil. Beberapa wanita yang mendapat informasi lengkap dan mengerti risiko dan komplikasi maternal dan fetal masih mungkin hamil, dan sayangnya wanita bisa hamil tanpa mendapat konseling prekonseptual yang tepat. Saat ini banyak wanita dengan sindroma Eisenmenger yang diterapi dengan vasodilator pulmonal. Diskusi prekonsepsi dengan dokter spesialis jantung mengenai terapi vasodilator pulmonal selama kehamilan penting dilakukan terutama bila wanita tersebut secara aktif mencoba untuk hamil, meskipun tidak disarankan, karena beberapa vasodilator bersifat teratogenik. Diskusi mengenai metode kontrasepsi harus dilakukan. Formula progesteron injeksi dan implan subdermal merupakan pilihan yang masuk akal. Pil progesteron tidak optimal karena tingkat efektivitasnya yang rendah. Pil kontrasepsi yang mengandung estrogen (pil kontrasepsi kombinasi) dikontraindikasikan karena risiko peningkatan tromboemboli.

Penggunaan intra-uterine contraceptive device dapat menyebabkan reaksi vasovagal, yang dapat membahayakan bagi wanita dengan hipertensi pulmonal. Beberapa wanita akan mempertimbangkan sterilisasi, karena risiko tinggi terjadinya kehamilan dengan alat kontrasepsi lain. Meskipun demikian, keputusan tersebut memiliki efek psikologis dan harus didiskusikan dengan pihak terkait. Selain itu, prosedur laparoskopik berisiko pada populasi wanita ini, karena memerlukan insuflasi abdomen dengan karbon dioksida, head down tilt intermiten, dan ventilasi tekanan positif, yang semuanya menurunkan cardiac output dan kemungkinan tidak dapat ditoleransi. Ada juga risiko emboli udara, yang dapat melewati shunt menuju ke otak (emboli paradoksikal) dalam kondisi right-to-left shunt. Bila dipilih sterilisasi, sangat direkomendasikan untuk dilakukan di pusat (kesehatan) dengan pengalaman merawat pasien dengan hipertensi pulmonal/sindroma Eisenmenger. Essure merupakan teknik sterilisasi baru, yang melibatkan insersi stent secara histeroskopik ke dalam tuba Fallopii menggunakan sedasi dan anestesi lokal. Studi awal menunjukkan bahwa teknik tersebut aman dengan tingkat kegagalan yang rendah. ${ }^{7}$

Perawatan Antepartum

Bila wanita dengan sindroma Eisenmenger hamil, 
perawatan yang terkoordinasi harus direncanakan dini, melibatkan spesialis penyakit jantung, obstetri, dan anestesi obstetri. Monitoring kardiovaskuler yang ketat dengan perhatian khusus pada status volume, penting dilakukan selama kehamilan dan periode peripartum. Ekokardiogram serial penting untuk menilai ukuran dan fungsi ventrikel kanan. Beberapa ahli memantau kadar natriuretic peptide tipe- $b$. Manajemen status volume wajib dilakukan. Hipovolemia dapat menyebabkan peningkatan right-to-left shunting, menurunkan cardiac output, dan hipoksemia refrakter. Demikian juga dengan overload volume juga harus dihindari karena tidak dapat diakomodasi oleh vaskuler pulmonal dan/atau ventrikel kanan yang telah terbebani, sehingga dapat menyebabkan terjadinya gagal jantung dan peningkatan rightto-left shunt. Follow-up harus sering dilakukan selama fase-fase akhir kehamilan dengan peningkatan cardiac output, dan dapat muncul penyakit vaskuler pulmonal. Terapi dengan vasodilator pulmonal harus didiskusikan dengan ahli hipertensi pulmonal. ${ }^{8,9}$

Sementara tidak ada vasodilator pulmonal yang benar-benar aman untuk kehamilan. Bila diperlukan, perawatan di rumah sakit yang dilengkapi dengan tim multidisiplin yang berpengalaman dalam manajemen penyakit jantung pada kehamilan dan hipertensi pulmonal penting dilakukan. Bergantung pada individunya, tirah baring dapat dipertimbangkan untuk menurunkan kebutuhan jantung. Terapi untuk gagal jantung mungkin diperlukan. Pasien tersebut juga berisiko mengalami tromboemboli. Penyakit tromboemboli pulmonal banyak ditemukan, bahkan pada wanita yang tidak hamil. Tromboprofilaksis penting diberikan saat pasien tersebut dalam kondisi tirah baring. Rencana antikoagulan yang sesuai harus diberikan dengan melibatkan ahli hematologis/trombosis. Bila diperlukan, ekokardiografi fetal dapat ditawarkan kepada ibu untuk screening defek jantung kongenital. Ekokardiogram fetal dilakukan pada sekitar kehamilan 20 minggu. ${ }^{9}$

\section{Persalinan}

Persalinan harus direncanakan dengan hati-hati dengan tim multidisiplin jauh hari sebelumnya. Rencana tersebut harus dikomunikasikan dengan pasien dan tim kesehatan lokal dan tersier. Persalinan pervaginam dan seksio sesarea yang berhasil banyak dilaporkan. Keputusan mengenai cara persalinan harus didasarkan pada individu pasien dan pengalaman dokter obstetri lokal. Bila persalinan per vaginam dipilih, manajemen nyeri yang baik sangat penting. Pemilihan teknik anestesia yang digunakan sepenuhnya merupakan keputusan ahli anestesi. Dapat dilakukan tindakan general anesthesia ataupun anestesi regional epidural. Jika menggunakan epidural, harus diberikan secara dini dan obat anestesi lokal diberikan dalam dosis kecil dan inkremental. Secara umum, baik general ataupun regional harus dihindari penurunan resistensi vaskuler perifer. Selama persalinan, manuver Valsava harus dihindari. ${ }^{7}$ Untuk menurunkan usaha mengejan selama fase aktif, forseps atau vakum sering digunakan. Untuk menurunkan potensi komplikasi yang membahayakan akibat persalinan yang sulit, kontraksi uterus sering digunakan untuk memfasilitasi penurunan bagian fetus yang terbawah. ${ }^{8,9}$ Pemilihan teknik anestesiuntuk seksio sesarea yang digunakan harus mempertimbangkan status hemodinamik parturien saat datang, tipe dari penyakit jantungnya, penggunaan obatobatan sebelumnya, serta jenis operasinya elektif atau cito. Anestesi regional merupakan kontraindikasi pada pasien dengan stenosis berat, hipoksia berat dan penggunaan antikoagulan. Pasien dengan NYHA kelas III dan IV sebaiknya tidak menggunakan anestesi spinal mengingat kemungkinan penurunan hemodinamiknya. Pada pasien dengan hemodinamik stabil, teknik anestesi epidural murni maupun kombinasi epiduralspinal dosis rendah menurut beberapa literatur lebih direkomendasikan daripada anestesi umum.

Anestesi umum diketahui mendepresi kontraktilitas jantung, meningkatkan resistensi pembuluh darah pulmoner melalui ventilasi tekanan positif. Tindakan laringoskopi dan intubasi serta kemungkinan aspirasi juga dapat menyebabkan perubahan hemodinamik pada pasien yang menjalani anestesi umum. ${ }^{8}$ Penurunan tekanan darah sebagai respon 
terhadap anestesi dapat berbahaya bagi wanita dengan sindroma Eisenmenger, sehingga tekanan darah harus dimonitor secara ketat. Obat uterotonik seperti oksitosin, yang menyebabkan vasodilatasi dan hipotensi arterial harus dihindari bila memungkinkan. Perdarahan postpartum (komplikasi dari penyakit jantung sianotik) harus segera diperhatikan dan diterapi secara agresif. Monitoring maternal seringkali meliputi telemetri, pulse oksimeter, dan monitoring tekanan darah invasif. Monitoring tekanan arteri pulmonal tidak rutin diindikasikan dan dapat berbahaya. Filter udara/ partikulat untuk semua akses intravena penting untuk wanita dengan sindroma Eisenmenger. Stoking kompresi atau thromboguards penting saat persalinan, bersama dengan ambulasi dini. ${ }^{8,10}$

\section{Perawatan Postpartum}

Risiko mortalitas tetap tinggi saat postpartum dan banyak ahli menyarankan periode monitoring postpartum yang panjang di rumah sakit. Perhatian pada status volume penting dilakukan. Setelah keluar dari rumah sakit, monitoring postpartum ketat perlu dilakukan. Perawatan harus berfokus pada manajemen status volume. Risiko komplikasi terkait kehamilan masih ada sampai 6 bulan postpartum saat perubahan hemodinamik terkait persalinan kembali ke saat sebelum hamil, sehingga follow-up ketat perlu dilakukan hingga 6 bulanpostpartum. ${ }^{10}$

\section{Simpulan}

Pada kehamilan terjadi perubahan fisiologi yang cukup signifikan di berbagai sistem organ. Perubahan tersebut secara fisiologis akan membebani jantung. Pasien dengan kelainan jantung yang mengalami kehamilan akan menerima beban yang semakin berat dan berisiko tinggi terjadinya gagal jantung. Teknik anestesi pada pasien dengan sindroma Eisenmenger memiliki perbedaan pendapat dari beberapa laporan kasus. Secara umum, baik general ataupun regional digunakan harus dihindari untuk menurunkan resistensi vaskuler perifer, maka lebih dipilih sedikit anestetik lokal dan lebih banyak narkotik. Pada anestesi regional, tidak terjadi manipulasi dari tekanan intratorakal dengan pemberian ventilasi tekanan positif melainkan dengan tarikan nafas pasif sesuai fisiologi pasien. Ventilasi tekanan positif berisiko memperberat hipertensi pulmonal yang terjadi. Selama persalinan, manuver valsava harus dihindari. Untuk menurunkan usaha mengejan selama fase aktif, forseps atau vakum sering digunakan. Untuk menurunkan potensi komplikasi yang membahayakan akibat persalinan yang sulit kontraksi uterus sering digunakan untuk memfasilitasi penurunan bagian fetus yang terbawah. Pemilihan teknik anestesi yang digunakan harus mempertimbangkan status hemodinamik parturien saat datang, tipe dari penyakit jantungnya, penggunaan obat-obatan sebelumnya, serta jenis operasinya elektif atau cito. Anestesi regional merupakan kontraindikasi pada pasien dengan stenosis kasus yang berat, hipoksia berat dan penggunaan antikoagulan. Pasien dengan NYHA kelas III dan IV sebaiknya tidak menggunakan anestesi spinal mengingat kemungkinan penurunan hemodinamiknya.

Pada pasien dengan hemodinamik stabil, teknik anestesi epidural murni maupun kombinasi epidural-spinal dosis rendah menurut beberapa literatur lebih direkomendasikan daripada anestesi umum. Anestesi umum diketahui mendepresi kontraktilitas jantung, meningkatkan resistensi pembuluh darah pulmoner melalui ventilasi tekanan positif. Tindakan laringoskopi dan intubasi serta kemungkinan aspirasi juga dapat menyebabkan perubahan hemodinamik pada pasien yang menjalani anestesi umum. Kemungkinan komplikasi pada pasien dengan sindroma Eisenmenger baik masalah kardiak (SVT, VT, CHF dan sudden death) maupun masalah non kardiak seperti perdarahan (perdarahan pulmonal, gastrointestinal, serebral), komplikasi iskemik (kejadian tromboembolik, emboli paradoksikal, emboli udara), disfungsi ginjal, hiperviskositas, dan lain lain harus menjadi kewaspadaan selama proses preoperasi, intraoperasi, dan paska operasi.

\section{Daftar Pustaka}

1. Boom, CE. Panduan Klinis Perioperatif Kardiovaskular Anestesia. Universitas 
Padjadjaran Bandung: Aksara Bermakna. 2013.

2. Gurumurthy T, Hegde R, Mohandas B. Anaesthesia for a patient with Eisenmenger's syndrome undergoing caesarean section. Indian Journal of Anaesthesia. 2012;56(3):291-294.

3. Gartner M, Youngblood C. Case report in anesthesiology: essential pulmonary hypertension in a primigravida. Anesthesiol Open J. 2016; 1(1): 24-27.

4. Fang, G, Tian Y. K., and Mei W. Anaesthesia management of caesarean section in two patients with Eisenmenger's Syndrome. Anesthesiology Research and Practice.

5. Grindheim G, Estensen ME, Langesaeter E, Rosseland LA, Toska K. Changes in blood pressure during healthy pregnancy: A longitudinal cohort study. J Hypertens.2012;30(2):342-50.
6. Neema, PK. Eisenmenger syndrome: An unsolved malady. Ann Card Anaesth 2012;15:257-8

7. Minicucci S, Segala V, Verdecchia. Safe management of caesaren section in a patient of Eisenmenger's Syndrome. Ann Card Anesth 2012; 15:296-8.

8. Isngadi, Rafidya IS. Manajemen Anestesi Pada Kehamilan Dengan Penyakit Jantung. Malang. Departemen Anestesiologi dan Terapi Intensif FKUB RSUD Dr.Saiful Anwar; 2017: 78.

9. Martin JT, Tautz TJ, Antognini JF. Safety of regional anaesthesia in Eisenmenger's syndrome. Reg Anesth Pain Med. 2002;27:509-13.

10. Partha M, Popli B, Nilofur B. Successful pregnancy outcome with Eisenmenger syndrome. J ObstetGynaecol India. 2012; 62(1):68-916. 2012.1-9. 